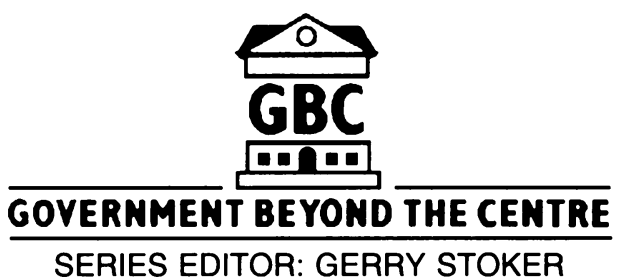

The world of sub-central government and administration - including local authorities, quasi-governmental bodies and the agencies of public-private partnerships - has seen massive changes in recent years and is at the heart of the current restructuring of government in the United Kingdom and other Western democracies.

The intention of the Government Beyond the Centre series is to bring the study of this often-neglected world into the mainstream of social science research, applying the spotlight of critical analysis to what has traditionally been the preserve of institutional public administration approaches.

Its focus is on the agenda of change currently being faced by subcentral government, the economic, political and ideological forces that underlie it, and the structures of power and influence that are emerging. Its objective is to provide up-to-date and informative accounts of the new forms of government, management and administration that are emerging.

The series will be of interest to students and practitioners of politics, public and social administration, and all those interested in the reshaping of the governmental institutions which have a daily and major impact on our lives. 


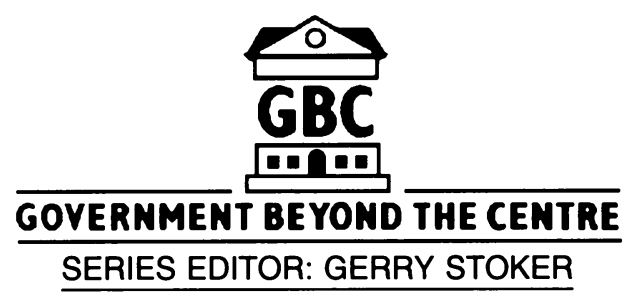

\section{Published}

Richard Batley and Gerry Stoker (eds)

Local Government in Europe

Clive Gray

Government Beyond the Centre

John Gyford

Citizens, Consumers and Councils

Richard Kerley

Managing in Local Government

Desmond King and Gerry Stoker (eds)

Rethinking Local Democracy

Steve Leach, John Stewart and Kieron Walsh

The Changing Organisation and Management of Local Government

Arthur Midwinter

Local Government in Scotland

Lawrence Pratchett and David Wilson (eds)

Local Democracy and Local Government

Yvonne Rydin

The British Planning System

John Stewart and Gerry Stoker (eds)

Local Government in the 1990 s

David Wilson and Chris Game (with Steve Leach and Gerry Stoker)

Local Government in the United Kingdom

Forthcoming

John Stewart

The Nature of British Local Government 


\title{
Local Democracy and Local Government
}

\author{
Edited by \\ Lawrence Pratchett \\ and \\ David Wilson
}

in association with

Macmillan Education 
Selection and editorial matter, and Chapters 1 and 12

(C) Lawrence Pratchett and David Wilson 1996

Other chapters (C) CLD Ltd 1994, 1995, 1996

Foreword (C) Simon Jenkins 1996

All rights reserved. No reproduction, copy or transmission of this publication may be made without written permission.

No paragraph of this publication may be reproduced, copied or transmitted save with written permission or in accordance with the provisions of the Copyright, Designs and Patents Act 1988, or under the terms of any licence permitting limited copying issued by the Copyright Licensing Agency, 90 Tottenham Court Road, London W1P 9HE.

Any person who does any unauthorised act in relation to this publication may be liable to criminal prosecution and civil claims for damages.

First published 1996 by MACMILLAN PRESS LTD

Houndmills, Basingstoke, Hampshire RG21 6XS

and London

Companies and representatives

throughout the world

ISBN 978-0-333-66433-9

DOI 10.1007/978-1-349-25022-6

A catalogue record for this book is available from the British Library.

$\begin{array}{rrrrrrrrrr}10 & 9 & 8 & 7 & 6 & 5 & 4 & 3 & 2 & 1 \\ 05 & 04 & 03 & 02 & 01 & 00 & 99 & 98 & 97 & 96\end{array}$

Copy-edited and typeset by Povey-Edmondson Okehampton and Rochdale, England

\section{Series Standing Order}

If you would like to receive future titles in this series as they are published, you can make use of our standing order facility. To place a standing order please contact your bookseller or, in case of difficulty, write to us at the address below with your name and address and the name of the series. Please state with which title you wish to begin your standing order. (If you live outside the UK we may not have the rights for your area, in which case we will forward your order to the publisher concerned.)

Standing Order Service, Macmillan Distribution Ltd, Houndmills, Basingstoke, Hampshire, RG21 6XS, England 


\section{Contents}

List of Tables and Figures

vii

Notes on the Contributors viii

Foreword by Simon Jenkins $\quad$ x

Preface xii

1 Local Government under Siege 1 Lawrence Pratchett and David Wilson

2 Why does Local Democracy Matter? 20 Anne Phillips

3 The Constitutional Status of Local Government 38 Martin Loughlin

4 Participation in Local Elections 62 Colin Rallings, Michael Temple and Michael Thrasher

5 Central Government Perceptions of Local Government 84 George Jones and Tony Travers

6 The Demise of the Public Service Ethos 106 Lawrence Pratchett and Melvin Wingfield

7 Political Parties and Local Democracy

Chris Game and Steve Leach

8 Quangos and Local Governance Alan Greer and Paul Hoggett

9 Reforming the New Magistracy John Stewart

10 Redefining Local Democracy Gerry Stoker

11 A Power of General Competence for Local Government Hilary Kitchin 
12 What Future for Local Democracy?

Lawrence Pratchett and David Wilson

Appendix: Summary of CLD Recommendations 250

Index

254 


\section{List of Tables and Figures}

Tables

1.1 DSO success by per cent number of contracts, June 1994-June 1995

1.2 Average population size of local authorities, $1994 \quad 13$

4.1 Average turnout in recent sub-national elections 64

4.2 Contestation and turnout in London elections 1964-90

4.3 Contestation and turnout in metropolitan elections $\quad 74$

4.4 Contestation and turnout in English shire elections 75

6.1 Profile of respondents with and without a sense of public service ethos

7.1 Party systems in local government, Great Britain, May 1995

7.2 Pattern of control of local authorities in Great Britain: May 1986, May 1993 and May 1995

\section{Figures}

6.1 Age range by belief in the public service ethos (PSE)

7.1 Local party networks (in a metropolitan district embracing three constituencies) 


\section{Notes on the Contributors}

Chris Game is Senior Lecturer in Local Government at the Institute of Local Government Studies (INLOGOV), University of Birmingham.

Alan Greer is Senior Lecturer in Politics, University of the West of England, Bristol.

Paul Hoggett is Professor and Associate Director, Centre for Social and Economic Research, University of the West of England, Bristol.

George Jones is Professor of Government at the London School of Economics and Political Science.

Hilary Kitchin is an Information Officer at the Local Government Information Unit.

Steve Leach is Professor of Local Government at De Montfort University, Leicester.

Martin Loughlin is Professor of Planning and Environmental Law, University of Manchester.

Anne Phillips is Professor of Politics, London Guildhall University.

Lawrence Pratchett is Senior Research Fellow in Local Government in the Department of Public Policy and Managerial Studies, De Montfort University, Leicester.

Colin Rallings is Director of the Local Government Chronicle's Election Centre at Plymouth University.

John Stewart is Professor of Local Government and Administration at the Institute of Local Government Studies (INLOGOV), University of Birmingham.

Gerry Stoker is Professor of Politics, University of Strathclyde, and co-ordinator of the five-year ESRC Local Governance Research Project. 
Michael Temple is Senior Lecturer in Politics at Staffordshire University.

Michael Thrasher is Director of the Local Government Chronicle's Election Centre at Plymouth University.

Tony Travers is Director of Research, Greater London Group, London School of Economics and Political Science.

David Wilson is Professor of Public Administration and Head of the Department of Public Policy and Managerial Studies, De Montfort University, Leicester.

Melvin Wingfield is a Research Student in the Department of Public Policy and Managerial Studies, De Montfort University, Leicester. 


\section{Foreword}

This book is an important addition to the work of the Commission for Local Democracy (CLD). It provides specially prepared versions of ten of the Commission's original research reports, as well as additional analysis of the Commission's findings and recommendations. Being rooted in the research of the CLD, this volume both complements its work and adds new dimensions to the debate which the Commission has begun.

The CLD was launched on 10 November 1993 to enquire into the state of local democracy in England and Wales and to consider its future. As an independent body our remit was not constrained by existing political or institutional concerns, nor directed by a particular ideological agenda. The Commissioners included former leaders of all three major parties in local government, as well as academics and former public servants. Our terms of reference gave us scope to investigate the definition and purpose of local democracy and its present institutional structure, to analyse the contribution made by other bodies involved in local administration, to draw upon the lessons to be learnt from the practice of local democracy in other countries, and to identify new forms of democratic participation. Consequently, we were able to consider the theory and practice of local democracy and to make recommendations on how democracy might be enhanced, both within the institutions of local government and beyond.

The Commission was created at a time of widespread fear on the part of many democrats that a vital element of the constitutional mix - the local element - has withered and is in danger of disappearing altogether. The centralisation of many services, the circumvention of local government and the diminution of local politics have all compounded to foster a democracy that increasingly ignores and belittles all things local and which gives excessive emphasis to national politics. The persistently low turn-out at local elections and the tendency for them to be used as indicators of national party preferences are symptomatic of this trend. The practice and habits of democracy at local level, which remains the foundation of our national democratic culture, are in retreat. We were concerned that, in recent years, democracy has become interpreted through the citizen as a consumer rather than an active 
participant in the political process. Against this background we set out to examine the challenges facing local democracy and to make recommendations about how its institutions might be modified.

The Commission was not alone in its concern. During our deliberations we were aware of other major research programmes being conducted by the Economic and Social Research Council, the Joseph Rowntree Foundation, the Local Government Management Board and the Department of the Environment. All touched on local democracy as part of their activities. Consequently, we saw part of our task as bringing together material from this research. Early in the Commission's life we established a sub-committee consisting of the late Kieron Walsh, Gerry Stoker, David Clark and Roger Jeffries which oversaw the Commission's research programme. Researchers were commissioned to produce their reports to tight deadlines within specific terms of reference. In total the CLD sponsored sixteen separate reports which it published between May 1994 and November 1995 and which covered a broad cross-section of political research. Much, though not all, is covered in this book. Copies of all of the Commission's research reports, as well as its final report Taking Charge: The Rebirth of Democracy, can be obtained from the Commission for Local Democracy, University of Greenwich, Churchill House, Wellington Street, London SE18 6PF.

In bringing the Commission's research together and providing fresh analysis of its findings, this book makes a valuable contribution to the debate on local democracy. Nothing but radical change can halt the drain of local democratic activity from British politics. This book develops the themes that were closest to our deliberations and which underpin the radical recommendations which we have made for the rebirth of local democracy.

Simon Jenkins Chair of the Commission for Local Democracy 


\section{Preface}

The Commission for Local Democracy was launched in November 1993 to inquire into the nature of local democracy in England and Wales and to consider its future development. Between then and the publication of its final report in June 1995, the Commission produced sixteen reports which guided its thinking and informed its final recommendations. This collection of essays incorporates ten specially commissioned versions of those reports, as well as two chapters contributed by the editors. This volume, therefore, both complements and develops the work of the Commission.

The co-operation of all the authors (especially those who had to fillet their original papers) was exemplary. The publishing deadlines were necessarily tight to retain topicality and without their cheerful co-operation this project would have run into the sand. We wish to thank all of them for making our task as editors considerably easier than it might have been.

A number of others also deserve acknowledgement for their support and assistance. David Clark, until recently Director of the Commission for Local Democracy, was an enthusiastic initiator of this project. Gerry Stoker provided careful guidance throughout, especially over the difficult decision of what papers to include and what to leave out. Our publisher, Steven Kennedy, was his usual enthusiastic self, offering encouragement from the outset and keeping the deadline in the forefront of our minds throughout. Our respective families have put up with much while we pressed on with the task in hand. Finally, we gratefully acknowledge the generous co-operation of CLD Ltd, and especially that of its chairperson, Dennis Reed, in allowing copyright material to be published for a wider readership in book form. We hope all involved will regard the end product as worthwhile.

Lawrence Pratchett

David WiLson 